\title{
A Farewell to the Man, But Not His Science
}

W ith the passing of A.D. Bradshaw on August 21, 2008, we lost the "father of restoration ecology." Tony Bradshaw lived a vibrant and productive 82 years, during which he became widely known among Ecological Restoration readers for calling restoration "an acid test for ecology" and for conceptualizing the degradation and restoration processes in a simple diagram (Bradshaw 1987a, 1987b).

In addition to his field research on the evolution of metal tolerance in grasses, Bradshaw also became well known for combining his knowledge of population genetics with his interest in healing derelict lands. As a result, the science of restoration ecology was born. Former Bradshaw Ph.D. student Janis Antonovics reminisced recently, "I remember being in the field, and seeing him appalled at the Forest Service trying to revegetate mine tailings in Wales using pieces of ordinary turf (that were just shriveling up)." Bradshaw's work helped make the practice of ecological restoration become more science-based. His discovery that grasses could evolve metal tolerance led practitioners to develop cultivars of colonial bentgrass (Agrostis capillaris) and red fescue (Festuca rubra) for use on contaminated tailings and soils. While most restorationists haven't had to face the challenge of restoring mine tailings, we probably all share some experience with urban-influenced restoration sites. According to Antonovics, "When [Bradshaw] got the Chair at Liverpool, rather than being discouraged by the 'city,' he had the vision and optimism to see urban ecology as a great opportunity ... something again that he talked about even before going there."

The threads that connect all of Bradshaw's work are plant genetics and evolution. For example, his last conference talk concerned the genetic basis of the "plasticity" of plants, which was the topic of his plenary talk and a recent publication (Bradshaw 2006b). At age 80, his advice on "new directions in plant ecological development" was still being sought by the Royal Society of London (Bradshaw 2006a).

The University of Wisconsin Arboretum's connection to Tony Bradshaw dates to 1984 , when William Jordan III organized a forward-looking conference of ecologists (including Michael Gilpin, Jared Diamond, Jack Ewel, Kay

Ecological Restoration Vol. 26, No. 4, 2008

ISSN 1522-4740 E-ISSN 1543-4079

(O2008 by the Board of Regents of the University of Wisconsin System.
Gross, and other notables) to consider how ecology might benefit from restoration activities, such as the planting and burning efforts used to restore native vegetation to Curtis Prairie. Jordan described Bradshaw to me as one of the few attendees who understood that science and practice could be reciprocal, each informing the other. "He was a very distinguished ecologist who responded productively and graciously to the idea of a symposium on restoration," Jordan told me. Don Waller similarly remembers Bradshaw's visit. "He clearly enjoyed his science and making it relevant to restoring heavy metal contaminated sites was part of the adventure for him," Waller told me.

Two outcomes of the 1984 conference were especially important for the UW Arboretum. First was a plan to focus on restoration research and establish a Chair in Restoration Ecology (Ewel 1984). Second was a book with two contributions from Bradshaw, both of which show his early vision of how restoration can inform the science and the practice can inform ecology (Jordan et al. 1987).

Bradshaw continued to influence restoration throughout his career. Many treatises on restoration, including a contribution in Science (Dobson et al. 1997), reprinted his conceptual drawing of the restoration process as the simultaneous linear decrease of both community structure and ecosystem functioning during degradation and the reverse during restoration. I was critical of his simplification of restoration and bothered by the lack of data in support of the model, since evidence fails to support a linear relationship between structure (usually plant diversity) and function (usually productivity) (Zedler and Lindig-Cisneros 2001). When I had the opportunity to discuss the matter with Bradshaw a few years ago, I asked if he had any supportive data. He thought for a moment and said, "Well, I guess it was a bit of a simplification." More recently, two students have joined me in testing his conceptual model of structure and function in prairies managed by the Arboretum (Jelinski et al. forthcoming, Doherty, unpub. data). The Jelinski test concerns an unplowed prairie that has been invaded by an aggressive clonal grass; the Doherty test concerns the Arboretum's oldest and most well-known restoration site, Curtis Prairie. In neither case is there evidence that supports a positive linear relationship between plant species diversity and productivity.

In retrospect, however, I believe his simple model can represent the toxic lands Bradshaw studied, where mining operations obliterate virtually every structural and 
functional component of an ecosystem, and where restorationists have to re-create the soil, plant metal-tolerant species, and wait decades for other biota to colonize. Over the long term and in a general sense, both structure and functioning increase as severely degraded sites undergo restoration. I am sad that we cannot discuss the alternative outcomes that my students and I have documented in different contexts. I hope he would be pleased that his ideas are stimulating further research and launching students' careers.

Tony Bradshaw's passing leaves a void in both our science and our practice. We cherish his contributions to the UW Arboretum, both in helping us focus on restoration ecology and in stimulating tests of his ideas. As we celebrate 75 years (1934-2009) of progress in restoration, research, and teaching, we also celebrate the contributions of those who played a role in shaping our efforts. We are proud that Professor Bradshaw is a part of that heritage.

\section{References:}

Bradshaw, A.D. 1987a. Restoration: An acid test for ecology. Pages 25-29 in W.R. Jordan III, M. Gilpin and J.D. Aber (eds), Restoration Ecology: A Synthetic Approach to Ecological Research. Cambridge UK: Cambridge University Press.

. 1987b. The reclamation of derelict land and the ecology of ecosystems. Pages 53-74 in W.R. Jordan III, M. Gilpin and J.D. Aber (eds), Restoration Ecology: A Synthetic Approach to Ecological Research. Cambridge UK: Cambridge University Press.
. 2006a. Unravelling phenotypic plasticity-why should we bother? Plenary presentation at the 14th New Phytologist Symposium, January 23-24. www.newphytologist.org/ eco-devo

. 2006b. Unravelling phenotypic plasticity-why should we bother? New Phytologist 170:644-648.

Dobson, A.P., A.D. Bradshaw and A.J.M. Baker. 1997. Hopes for the future: Restoration ecology and conservation biology. Science 277:515-522.

Ewel, J.J. 1984. Summary and synthesis of advisory panel discussion on Arboretum research at the University of Wisconsin. University of Wisconsin-Madison Arboretum Archives.

Jelinski, N.A., C.J. Kucharik and J.B. Zedler. Forthcoming. A test of diversity-productivity models in natural, degraded, and restored prairie ecosystems. Restoration Ecology.

Jordan, W.R., III, M. Gilpin and J.D. Aber. 1987. Restoration Ecology: A Synthetic Approach to Ecological Research. Cambridge UK: Cambridge University Press.

Zedler, J.B. and R. Lindig-Cisneros. 2001. Functional equivalency of restored and natural salt marshes. Pages 565-582 in M. Weinstein and D. Kreeger (eds), Concepts and Controversies in Tidal Marsh Ecology. Dordrecht, The Netherlands: Kluwer.

Respectfully submitted,

Joy Zedler, Aldo Leopold Chair of Restoration Ecology

University of Wisconsin Arboretum, Madison 